\title{
PENGARUH PERANAN PENGGUNA AKHIR, PROSEDUR, DATA, PERANGKAT KERAS DAN MANAJEMEN PROYEK TERHADAP KEBERHASILAN IMPLEMENTASI ERP: STUDI KASUS PT CILIANDRA PERKASA
}

\author{
Roni Kurniawan \\ Information Systems Department, School of Information Systems, Binus University \\ Jl. K.H. Syahdan No. 9, Palmerah, Jakarta Barat 11480 \\ ronikurniawan.binus@yahoo.com
}

\begin{abstract}
Information technology improvement is one of drivers that changes in computer-based accounting information system called Enterprise Resource Planning (ERP) System. The advantages of ERP system leads companies decide to eventually implement the system. The objective of this study is to comprehend the impacts of some variables such as end-user role, procedure, data, hardware and project management to the success of ERP implementation, both partially and simultantly.This research implements descriptive analysis method where the data are collected by questionare on a survey. Population is a company of oil-palm industry located in Pekanbaru - Riau which implements ERP system for its operational. Data are proccessed using SPSS version 17.00 and hypothesis testing is performed using statistic tests, which are validation test, reliability test and double regression test. The result and discussion of this study in general shows that end-user role, procedure, data, hardware and project management variables have positive correlation and influence to the success of ERP implementation, both partially and simultantly.
\end{abstract}

Keywords: end-users, procedure, data, hardware, project management

\begin{abstract}
ABSTRAK
Kemajuan teknologi informasi merupakan salah satu penggerak terjadinya perubahan dalam sistem informasi akuntansi yang berbasis komputer yang dikenal dengan istilah Enterprice Resource Planning system (ERP) system. Keunggulan sistem ERP menyebabkan semakin banyak perusahaan memutuskan untuk mengimplementasikan sistem tersebut. Tujuan dari penelitian ini adalah untuk mengetahui pengaruh atas beberapa variabel, yaitu peranan pengguna akhir, prosedur, data, perangkat keras dan manajemen proyek terhadap keberhasilan implementasi ERP baik secara parsial ataupun secara simultan. Penelitian ini menggunakan metode deskriptif analisis di mana pengumpulan data menggunakan survei melalui kuosioner. Populasi penelitian ini adalah perusahaan di bidang perkebunan kelapa sawit, berlokasi di Pekanbaru - Riau yang telah menggunakan sistem ERP untuk kegiatan operasional sehari-hari. Data diolah menggunakan SPSS versi 17.00 dan pengujian hipotesis penelitian dilakukan menggunakan uji statistik, yaitu uji validitas, uji realibilitas dan regresi berganda. Hasil penelitian dan pembahasan secara umum menunjukkan bahwa variable pengguna akhir, prosedur, data, perangkat keras dan manajemen proyek mempunyai korelasi positif dan mempengaruhi keberhasilan implementasi ERP baik secara parsial maupun secara simultan.
\end{abstract}

Kata kunci: pengguna akhir, prosedur, data, perangkat keras, manajemen proyek 


\section{PENDAHULUAN}

Perkembangan teknologi dan era globalisasi menjadi salah satu penggerak utama yang menyebabkan sistem informasi akuntansi saat ini telah berkembang menjadi sistem yang berbasis komputer. Perkembangan teknologi informatika juga menyebabkan semakin mudahnya ketersediaan informasi atas pengungkapan informasi akuntansi bagi manajemen mulai dari manajemen tingkat atas, menengah dan tingkat bawah.

Agar suatu organisasi dapat menikmati keunggulan yang diberikan sistem informasi akuntansi berbasis komputer yang juga secara langsung berdampak terhadap kegiatan perusahaan, organisasi bisnis perlu mengimplementasikan suatu sistem teknologi informasi yang terintegrasi, yang mempunyai fungsi berkaitan dengan proses penginputan dan pengolahan data dimulai dari pemesanan barang, persediaan, produksi, distribusi dan finance atau accounting. Fungsi yang saling berkaitan dan terhubung satu dengan yang lainnya yang menimbulkan informasi akuntansi pada akhirnya dapat dioptimalisasikan penggunaannya dan bermanfaat bagi seluruh lini perusahaan. Sistem ini dikenal sebagai Enterprise Resource Planning (ERP).

Sistem ERP (Enterprise Resource Planning) dalam (Turban, 2006, 311) adalah software yang mengintegrasikan proses perencanaan, manajemen dan penggunaan semua sumber daya dalam suatu perusahaan. Sistem ERP yang dikemas dalam suatu aplikasi perangkat lunak (software) yang dapat diterapkan pada suatu organisasi atau perusahaan dan disiapkan untuk meningkatkan dan mengintegrasikan proses-proses dalam internal perusahaan, seperti sistem sumber daya manusia, sistem keuangan, penjualan, produksi dan seterusnya.

Untuk dapat mengimplementasikan ERP dalam suatu perusahaan dengan sukses, manajemen perusahaan perlu melakukan analisis mengenai beberapa hal, antara lain mengenai manfaat, dana yang dibutuhkan, lamanya waktu implementasi, dukungan manajemen dan karyawan perusahaan atas perubahan yang terjadi dan juga dukungan lainnya dalam hal perangkat keras (hardware) dan infrastruktur perusahaan.

Pada kesempatan ini akan dilakukan penelitian untuk menentukan pengaruh peranan pengguna akhir, prosedur, data, perangkat keras dan manajemen proyek terhadap keberhasilan implementasi Enterprise Resource Planning pada PT PT Ciliandra Perkasa.

PT Ciliandra Perkasa didirikan di Jakarta pada tanggal 31 Juli 1992. Perusahaan ini adalah salah satu produsen swasta minyak sawit terbesar di Indonesia. Saat ini PT Ciliandra Perkasa telah memiliki 13 lahan perkebunan siap produksi dan 6 lahan perkebunan kelapa sawit yang berlokasi di Pulau Sumatra, provinsi Riau, Indonesia. PT Ciliandra Perkasa telah mencapai level tinggi dalam kompetisi bisnis yang telah ada saat ini dan sekarang hendak menggabungkan diri kepada bisnis hilir untuk menambah nilai produk. Sebagai contoh, PT Ciliandra Perkasa telah berinvestasi pada industri biodiesel. PT Ciliandra berharap atas pengembangan usaha ini dari waktu ke waktu semakin meningkat.

Seiring dengan berkembangnya perusahaan, bisnis proses perusahaan pun berkembang semakin kompleks. Untuk itulah perusahaan mengambil langkah strategis dengan mengimplementasikan Sistem ERP (Enterprise Resource Planning) untuk mengintegrasikan beberapa sub bisnis proses menjadi satu kesatuan. Beberapa sub bisnis proses tersebut antara lain: Sales, Purchasing, Inventory, Accounting (General Ledger, Fixed Asset) dan Finance (Account Payable, Account Receivable \& Cash Management). Pengguna Sistem ERP tersebar di beberapa departemen, antara lain: department Sales, Purchasing, Accounting, Finance dan Logistik. 
Berdasarkan latar belakang sebagaimana telah terurai di atas, dapat dirumuskan permasalahan sebagai berikut: (1) apakah Pengguna Akhir $\left(\mathrm{X}_{1}\right)$ berpengaruh terhadap Keberhasilan Implementasi ERP (Y)? (2) apakah Prosedur $\left(\mathrm{X}_{2}\right)$ berpengaruh terhadap Keberhasilan Implementasi ERP (Y)? (3) apakah Data $\left(\mathrm{X}_{3}\right)$ berpengaruh terhadap Keberhasilan Implementasi ERP (Y)? (4) apakah Perangkat Keras $\left(\mathrm{X}_{4}\right)$ berpengaruh terhadap Keberhasilan Implementasi ERP (Y)? (5) apakah Manajemen Proyek $\left(\mathrm{X}_{5}\right)$ berpengaruh terhadap Keberhasilan Implementasi ERP (Y)? (6) apakah Pengguna Akhir $\left(\mathrm{X}_{1}\right)$, Prosedur $\left(\mathrm{X}_{2}\right)$, Data $\left(\mathrm{X}_{3}\right)$, Perangkat Keras $\left(\mathrm{X}_{4}\right)$ dan Manajemen Proyek $\left(\mathrm{X}_{5}\right)$ secara bersamasama berpengaruh terhadap Keberhasilan Implementasi ERP (Y)?

Melalui penelitian ini dapat diuraikan beberapa tujuan yang akan dicapai, antara lain: (1) kajian tentang pengaruh peranan pengguna akhir terhadap Implementasi ERP; (2) kajian tentang pengaruh peranan prosedur terhadap Implementasi ERP; (3) kajian tentang pengaruh peranan data terhadap Implementasi ERP; (4) kajian tentang pengaruh peranan perangkat keras terhadap Implementasi ERP; (5) kajian tentang pengaruh peranan manajemen proyek terhadap Implementasi ERP; (6) variabel yang paling berpengaruh antara pengguna akhir, prosedur, data, perangkat keras dan manajemen proyek terhadap keberhasilan implementasi ERP.

\section{METODE}

Penelitian dilakukan di PT Ciliandra Perkasa, Gedung Surya Dumai lantai 5, Jl. Jenderal Sudirman 395 Pekanbaru 28116. Proses penelitian yang dilakukan penulis dilakukan sejak Desember 2012. Tipe penelitian yang digunakan adalah survei sedangkan metode penelitiannya adalah deskriptif analisis. Metode survei deskriptif adalah metode penelitian yang menggunakan sampel dari populasi dan menggunakan kuesioner sebagai alat pengumpulan data. Data dan informasi penelitian ini diperoleh dari responden dengan menggunakan kuesioner. Setelah data diperoleh maka langkah selanjutnya adalah memaparkan hasilnya secara deskriptif dan pada akhir penelitian akan dianalisis untuk menguji hipotesis yang diajukan pada awal penelitian.

Penelitian ini menguji hipotesis dengan menggunakan metode analisis jalur (path analysis) dengan dukungan perangkat lunak (software) Statistical Package for the Social Scene (SPSS) versi 17.0. Mengingat skala yang digunakan dalam penelitian ini adalah skala Likert, data harus terlebih dahulu diuji. Penelitian yang mengukur variabel dengan menggunakan instrumen kuesioner harus dilakukan pengujian kualitas terhadap data yang diperoleh. Pengujian ini bertujuan untuk mengetahui apakah instrumen yang digunakan valid dan reliable sebab kebenaran data yang diolah sangat menentukan kualitas hasil penelitian. Hipotesis yang dilakukan dalam penelitian ini meliputi uji Regresi dan uji Hipotesis.

\section{Konsep Dasar Pengguna Akhir}

Informasi bernilai guna yang merupakan manfaat dari sistem informasi pada akhirnya diperuntukkan oleh pengguna akhir (end user) dari berbagai level dan lini manajemen dalam suatu organisasi bisnis. Pengguna akhir dapat meliputi para manajer, non manajer dan juga orang-orang dan organisasi dalam lingkungan perusahaan.

\section{Konsep Dasar Prosedur}

Standar Operasional Prosedur adalah pedoman atau acuan untuk melaksanakan tugas pekerjaan sesuai dengan fungsi dan alat penilaian kinerja suatu unit bisnis berdasarkan indikator indikator teknis, administrasif dan prosedural sesuai dengan tata kerja, prosedur kerja dan sistem kerja 
pada unit kerja yang bersangkutan (Dhewanto dan Falahah, 2007). Tujuan Standar Operasional Prosedur adalah menciptakan komitmen mengenai apa yang dikerjakan oleh satuan unit kerja untuk mewujudkan good governance. Dilihat dari fungsinya, SOP berfungsi membentuk sistem kerja dan aliran kerja yang teratur, sistematis, dan dapat dipertanggungjawabkan; menggambarkan bagaimana tujuan pekerjaan dilaksanakan sesuai dengan kebijakan dan peraturan yang berlaku; menjelaskan bagaimana proses pelaksanaan kegiatan berlangsung; sebagai sarana tata urutan dari pelaksanaan dan pengadministrasian pekerjaan harian sebagaimana metode yang ditetapkan; menjamin konsistensi dan proses kerja yang sistematik; dan menetapkan hubungan timbal balik antar satuan kerja. Sebagai suatu instrumen manajemen, SOP berlandaskan pada sistem manajemen kualitas (Quality Management System), yakni sekumpulan prosedur terdokumentasi dan praktek-praktek standar untuk manajemen sistem yang bertujuan menjamin kesesuaian dari suatu proses dan produk (barang dan/atau jasa) terhadap kebutuhan atau persyaratan tertentu. Sistem manajemen kualitas berfokus pada konsistensi dari proses kerja. Hal ini mencakup beberapa tingkat dokumentasi terhadap standar-standar kerja. Sistem ini berlandaskan pada pencegahan kesalahan, sehingga bersifat proaktif, bukan pada deteksi kesalahan yang bersifat reaktif.

\section{Konsep Dasar Data}

Sistem informasi tidak dapat dipisahkan dari salah satu elemen dasar yang merupakan bagian sangat penting, yaitu data. Menurut Turban, Mclean and Wetherbe (2001:45), konsep mengenai data dalam sistem informasi adalah: "Data items refer to an elementary description of things, events, activities and transactions that are recorded, classified and stored but not organized to convey any specific meaning. Data items can be numeric, alphanumeric, fiures, sounds or images. A database consists of stored data items organized for retrieval."

\section{Konsep Dasar Perangkat Keras}

Definisi perangkat keras (hardware) menurut Turban et al. (2001) adalah "Hardware is the physical equipment, media and attached devices used in a computer system". Stair and Reynolds (2008) menyatakan definisi hardware: "computer equipment used to perform input, processing, storage, and output activities in an information system". Perangkat keras (Hardware) menurut Mcleod (2001) muncul dengan beragam kecepatan pada berbagai harga tetapi semuanya memiliki ciri-ciri yang sama.

\section{Konsep Dasar Manajemen Proyek}

Menurut Meredith and Mantel (2000), proyek didefinisikan sebagai "A temporary endeavor undertaken to create a unique product or service". Proyek dianggap sebagai suatu pekerjaan yang memiliki spesifikasi khusus, tujuan yang unik dan memiliki jangka waktu tertentu yang berbeda-beda sehingga diperlukan manajemen khusus sehingga proyek dapat direncanakan, dikelola dengan baik untuk mencapai tujuannya secara efektif dan efisien. Beberapa atribut yang spesifik tersebut itulah yang menyebabkan implementasi ERP System dianggap sebagai proyek karena adanya tiga dimensi utama yang mendasari implementasi sistem.

\section{Kerangka Pemikiran}

Alur pemikiran yang akan dituangkan sebagai kerangka pemikiran dapat dilihat pada Gambar 1 berikut ini. 


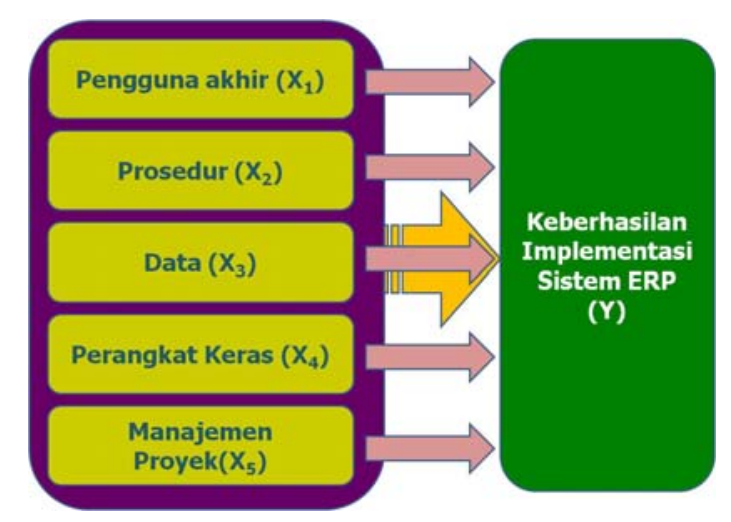

Gambar 1 Skema kerangka penelitian

(Sumber: diolah oleh penulis)

Variabel pertama, yaitu pengguna akhir dan meneliti apakah variabel pengguna akhir tetap konsisten mempunyai korelasi positif dan mempengaruhi keberhasilan atas implementasi sistem ERP dalam sampel dan ruang lingkup penelitian yang berbeda. Variabel kedua, yaitu prosedur dan meneliti apakah variabel prosedur mempunyai korelasi positif dan mempengaruhi keberhasilan atas implementasi sistem ERP. Variabel ketiga, yaitu data dan meneliti apakah variabel data mempunyai korelasi positif dan mempengaruhi keberhasilan atas implementasi sistem ERP. Variabel keempat, yaitu perangkat keras dan meneliti apakah variabel perangkat keras mempunyai korelasi positif dan mempengaruhi keberhasilan atas implementasi sistem ERP. Variabel kelima, yaitu manajemen proyek dan meneliti apakah variabel manajemen proyek mempunyai korelasi positif dan mempengaruhi keberhasilan atas implementasi sistem ERP.

Hipotesis yang diuji dalam penelitian ini adalah sebagai berikut:

(1). Ha: Pengguna akhir berpengaruh terhadap Keberhasilan implementasi ERP.

(2). Ha: Prosedur berpengaruh terhadap Keberhasilan implementasi ERP.

(3). Ha: Data berpengaruh terhadap Keberhasilan implementasi ERP.

(4). Ha: Perangkat Keras berpengaruh terhadap Keberhasilan implementasi ERP.

(5). Ha: Manajemen Proyek berpengaruh terhadap Keberhasilan implementasi ERP.

(6). Ha: Pengguna akhir, Prosedur, Data, Perangkat Keras, Manajemen Proyek secara simultan berpengaruh terhadap Keberhasilan implementasi ERP.

\section{HASIL DAN PEMBAHASAN}

\section{Pengaruh Pengguna Akhir $\left(\mathrm{X}_{1}\right)$ terhadap Keberhasilan Implementasi ERP}

$\mathrm{Ha}_{1}$ : Terdapat pengaruh Pengguna Akhir terhadap Keberhasilan Implementasi ERP

Pengaruh secara parsial dari Pengguna Akhir terhadap Keberhasilan Implementasi ERP dapat dilakukan dengan membandingkan besarnya $p$-value pada kolom Sig. dengan level of significant sebesar 0,05. Standarized Coefficients menghasilkan angka untuk $X_{1}$ sebesar 1,141. Hal ini memberikan pengertian bahwa terdapat pengaruh sebesar 1,141 dari Pengguna Akhir (X1) terhadap Keberhasilan Implementasi ERP. Berdasarkan tabel itu pula, diperoleh variabel Pengguna Akhir memiliki nilai $p$-value pada kolom Sig. $0,000<0.05$ level of significant $(\alpha)$ dengan demikian artinya dengan hasil ini maka dapat diintepretasikan bahwa dukungan dan kerjasama pengguna akhir untuk menggunakan sistem ERP yang diimplementasikan dapat membantu keberhasilan proses implementasi 
ERP. Dengan demikian hipotesis pertama yaitu Hal yang menyatakan bahwa "pengguna akhir berpengaruh terhadap keberhasilan implementasi ERP" terbukti benar.

\title{
Pengaruh Prosedur $\left(\mathrm{X}_{2}\right)$ terhadap Keberhasilan Implementasi ERP
}

\author{
$\mathrm{Ha}_{2}$ : Terdapat pengaruh Prosedur terhadap Keberhasilan Implementasi ERP
}

Pengaruh secara parsial dari Prosedur terhadap Keberhasilan Implementasi ERP dapat dilakukan dengan membandingkan besarnya $p$-value pada kolom Sig. dengan level of significant sebesar 0,05. Standarized Coefficients menghasilkan angka untuk $\mathrm{X}_{2}$ sebesar 0,614. Hal ini memberikan pengertian bahwa terdapat pengaruh sebesar 0,614 dari Prosedur $\left(\mathrm{X}_{2}\right)$ terhadap Keberhasilan Implementasi ERP. Berdasarkan tabel itu pula, diperoleh variabel Prosedur memiliki nilai $p$-value pada kolom Sig. $0,000<0.05$ level of significant $(\alpha)$ dengan demikian artinya dengan hasil ini dapat diintepretasikan bahwa prosedur yang terperinci dengan beberapa kriteria di antaranya, yaitu memiliki aliran kerja yang sistematis, sistem pengendalian internal dan urutan prosedur kerja yang jelas dapat membantu proses implementasi sistem ERP berjalan dengan lancar dan proses mapping antara prosedur dan sistem ERP yang diimplementasikan berjalan lebih lancar sehingga pada akhirnya dapat menunjang keberhasilan implementasi ERP. Dengan demikian hipotesis kedua yaitu $\mathrm{Ha} 2$ yang menyatakan bahwa "prosedur berpengaruh terhadap keberhasilan implementasi ERP" terbukti benar.

\section{Pengaruh Data $\left(\mathrm{X}_{3}\right)$ terhadap Keberhasilan Implementasi ERP}

$\mathrm{Ha}_{3}$ : Terdapat pengaruh Data terhadap Keberhasilan Implementasi ERP.

Pengaruh secara parsial dari Data terhadap Keberhasilan Implementasi ERP dapat dilakukan dengan membandingkan besarnya $p$-value pada kolom Sig. dengan level of significant sebesar 0,05. Standarized Coefficients menghasilkan angka untuk $X_{3}$ sebesar 1,084. Hal ini memberikan pengertian bahwa terdapat pengaruh sebesar 1,084 dari Data $\left(\mathrm{X}_{3}\right)$ terhadap Keberhasilan Implementasi ERP. Berdasarkan tabel itu pula, diperoleh variabel Data memiliki nilai p-value pada kolom Sig. 0,000< 0.05 level of significant $(\alpha)$ dengan demikian artinya dengan hasil ini maka dapat diintepretasikan bahwa Data yang akurat dan dibantu dengan adanya dukungan dari fitur sistem ERP untuk menghasilkan proses penginputan dan pengolahan data dengan lebih sistematis, akurat dan tepat waktu dapat membantu proses penciptaan informasi akuntansi dengan lebih cepat, mudah dan mempunyai nilai tambah yang tinggi dan dapat membantu manajemen dalam pengambilan keputusan. Hal ini mempengaruhi keberhasilan implementasi sistem ERP. Dengan demikian hipotesis ketiga yaitu Ha3 yang menyatakan bahwa "data berpengaruh terhadap keberhasilan implementasi ERP" terbukti benar.

\section{Pengaruh Perangkat Keras $\left(\mathrm{X}_{4}\right)$ terhadap Keberhasilan Implementasi ERP}

$\mathrm{Ha}_{4}$ : Terdapat pengaruh Perangkat Keras terhadap Keberhasilan Implementasi ERP

Pengaruh secara parsial dari Perangkat Keras terhadap Keberhasilan Implementasi ERP dapat dilakukan dengan membandingkan besarnya p-value pada kolom Sig. dengan level of significant sebesar 0,05. Standarized Coefficients menghasilkan angka untuk $\mathrm{X}_{4}$ sebesar 1,290. Hal ini memberikan pengertian bahwa terdapat pengaruh sebesar 1,290 dari Perangkat Keras $\left(\mathrm{X}_{4}\right)$ terhadap Keberhasilan Implementasi ERP.Berdasarkan tabel itu pula, diperoleh variabel Perangkat Keras memiliki nilai $p$-value pada kolom Sig. $0,000<0.05$ level of significant $(\alpha)$ dengan demikian artinya signifikan dan dengan hasil ini maka dapat diintepretasikan bahwa Perangkat Keras yang sesuai dan mempunyai spesifikasi produk seimbang dengan sistem ERP yang digunakan dapat membantu kelancaran proses implementasi sehingga mempunyai pengaruh terhadap keberhasilan implementasi 
sistem ERP. Dengan demikian hipotesis keempat yaitu Ha4 yang menyatakan bahwa "perangkat keras berpengaruh terhadap keberhasilan implementasi ERP" terbukti benar.

\section{Pengaruh Manajemen Proyek $\left(\mathrm{X}_{5}\right)$ terhadap Keberhasilan Implementasi ERP}

$\mathrm{Ha}_{5}$ : Terdapat pengaruh Manajemen Proyek terhadap Keberhasilan Implementasi ERP

Pengaruh secara parsial dari Manajemen Proyek terhadap Keberhasilan Implementasi ERP dapat dilakukan dengan membandingkan besarnya $p$-value pada kolom Sig. dengan level of significant sebesar 0,05. Standarized Coefficients menghasilkan angka untuk $\mathrm{X}_{5}$ sebesar 1,062. Hal ini memberikan pengertian bahwa terdapat pengaruh sebesar 1,062 dari Manajemen Proyek $\left(\mathrm{X}_{5}\right)$ terhadap Keberhasilan Implementasi ERP. Berdasarkan tabel itu pula, diperoleh variabel Manajemen Proyek memiliki nilai $p$-value pada kolom Sig. $0,000<0.05$ level of significant $(\alpha)$ dengan demikian artinya signifikan dan dengan hasil ini maka dapat diintepretasikan bahwa keterlibatan manajemen proyek dalam proses implementasi sistem ERP dan dukungan manajemen proyek dapat membantu untuk mendeteksi persoalan yang terjadi selama implementasi sistem ERP berlangsung dan dapat meminimalisasi masalah yang lebih besar sehingga pada akhirnya dapat membantu menunjang keberhasilan implementasi sistem ERP. Dengan demikian hipotesis kelima yaitu Ha5 yang menyatakan bahwa "manajemen proyek berpengaruh terhadap keberhasilan implementasi ERP" terbukti benar.

\section{Pengaruh Pengguna Akhir $\left(X_{1}\right)$, Prosedur $\left(X_{2}\right)$, Data $\left(X_{3}\right)$, Perangkat Keras $\left(X_{4}\right)$ dan Manajemen Proyek $\left(X_{5}\right)$ terhadap Keberhasilan Implementasi ERP}

$\mathrm{Ha}_{6}$ : Terdapat pengaruh Pengguna Akhir $\left(\mathrm{X}_{1}\right)$, Prosedur $\left(\mathrm{X}_{2}\right)$, Data $\left(\mathrm{X}_{3}\right)$, Perangkat Keras $\left(\mathrm{X}_{4}\right)$ dan Manajemen Proyek $\left(\mathrm{X}_{5}\right)$ terhadap Keberhasilan Implementasi ERP

Seperti yang terlihat di tabel Anova pada lampiran output SPSS, nilai F sebesar 775,012 dengan nilai Sig. sebesar 0,000 yang berarti lebih kecil dari 0,05 maka memberikan pengertian bahwa model regresi ini layak untuk digunakan dalam memprediksi hubungan antara variabel bebas dan variabel terikatnya.

Sedangkan hipotesis dalam uji $\mathrm{F}$ adalah:

$\mathrm{H}_{0}: \quad \mathrm{b}_{1}=\mathrm{b}_{2}=\mathrm{b}_{3}=\mathrm{b}_{4}=\mathrm{b}_{5}=0$ maka variabel bebas secara bersama-sama tidak berpengaruh terhadap variabel terikat.

$H_{1}: b_{1}, b_{2}, b_{3}, b_{4}, b_{5} \neq 0$ maka variabel bebas secara bersama-sama ber-pengaruh terhadap variabel terikat.

Untuk mengetahui ada tidaknya pengaruh variabel bebas secara bersama-sama terhadap variabel terikat maka dilakukan uji F. Bila nilai Fhitung lebih besar dari Ftabel maka dinyatakan setidaknya ada satu variabel bebas yang memberikan kontribusi untuk memprediksi nilai variabel terikatnya. Sebaliknya jika Fhitung lebih kecil dari Ftabel maka dinyatakan tidak ada satu pun variabel bebas yang memberikan kontribusi untuk memprediksi nilai variabel terikatnya.

Nilai $F_{\text {hitung }}$ diperoleh dari nilai $F$ pada tabel Anova sebsesar 775,012 (Sig. sebesar 0,000), di mana:

Nilai $F_{\text {hitung }}$ lebih besar dari $F_{\text {tabel }}$ sesuai dengan tingkat signifikansinya dan tingkat df (degree of freedom). Hal ini menunjukan bahwa Pengguna Akhir $\left(\mathrm{X}_{1}\right)$, Prosedur $\left(\mathrm{X}_{2}\right)$, Data $\left(\mathrm{X}_{3}\right)$, Perangkat Keras $\left(\mathrm{X}_{4}\right)$ dan Manajemen Proyek $\left(\mathrm{X}_{5}\right)$ terhadap Keberhasilan Implementasi ERP dikarenakan 
implementasi sistem ERP dapat berhasil dengan adanya dukungan Pengguna Akhir yang bersedia dan mampu menggunakan sistem ERP secara maksimal, adanya dukungan Prosedur yang sistematis yang dimiliki oleh perusahaan dan dapat dipetakan dengan baik dalam sistem, adanya dukungan Data input, proses penginputan dan pengolahan data yang lebih akurat dan sistematis dalam sistem, adanya Perangkat Keras yang mempunyai spesifikasi dan kemampuan yang selaras dengan sistem ERP dan ketersediaan Manajemen Proyek sebagai faktor yang mendukung besarnya tingkat pencapaian keberhasilan implementasi ERP secara positif. Dengan demikian hipotesis keenam yaitu Ha6 yang menyatakan bahwa "Pengguna Akhir $\left(\mathrm{X}_{1}\right)$, Prosedur $\left(\mathrm{X}_{2}\right)$, Data $\left(\mathrm{X}_{3}\right)$, Perangkat Keras $\left(\mathrm{X}_{4}\right)$ dan Manajemen Proyek $\left(\mathrm{X}_{5}\right)$ secara simultan berpengaruh terhadap Keberhasilan implementasi ERP (Y)" terbukti benar.

Koefisien Determinasi menunjukan besarnya peranan dan kontribusi $\mathrm{X}_{1}$ dalam pembentukan variabel $\mathrm{Y}$, besarnya peranan dan kontribusi $\mathrm{X}_{2}$ dalam pembentukan variabel $\mathrm{Y}$, besarnya peranan dan kontribusi $\mathrm{X}_{3}$ dalam pembentukan variabel $\mathrm{Y}$, besarnya peranan dan kontribusi $\mathrm{X}_{4}$ dalam pembentukan variabel $\mathrm{Y}$ dan besarnya peranan dan kontribusi $\mathrm{X}_{5}$ dalam pembentukan variabel $\mathrm{Y}$ dinyatakan dalam angka presentase. Koefisien determinasi dapat diperoleh dengan mengkuadratkan koefisien korelasi (r2). Dari tabel Model Summary pada lampiran output SPSS dapat dilihat bahwa Adjusted R square berada pada hitungan 0,934 atau secara presentase 93,4\% dari variabel terikat, Keberhasilan implementasi sistem ERP dapat dijelaskan oleh variabel pengguna akhir, prosedur, data, perangkat keras dan manajemen proyek.

Dengan demikian dapat dikatakan bahwa 93,4\% Keberhasilan Implementasi ERP dipengaruhi oleh Pengguna Akhir, Prosedur, Data, Perangkat Keras dan Manajemen Proyek. Dalam bidang Sistem Informasi, kelima variabel tersebut merupakan variabel yang sangat berpengaruh secara bersama-sama karena masing-masing mempunyai keterkaitan satu dengan lainnya yang mampu memperbesar tingkat keberhasilan implementasi sistem ERP. Sedangkan 6,6\% dipengaruhi oleh variabel lainnya yang diduga adalah peran sumber daya manusia dan faktor-faktor lain yang ada dalam perusahaan.

\section{PENUTUP}

Berdasarkan hasil analisis yang telah diuraikan pada bab sebelumnya, dapat disimpulkan sebagai berikut: (1) hasil penelitian ini menyatakan bahwa ada pengaruh Pengguna Akhir $\left(\mathrm{X}_{1}\right)$ dengan Keberhasilan Implementasi ERP (Y) yaitu sebesar 1,141. Hasil ini konsisten jika dibandingkan dengan hasil penelitian lainnya sehingga dapat disimpulkan terdapat konsistensi antara Pengguna Akhir dan Keberhasilan Implementasi sistem ERP; (2) hasil penelitian ini menyatakan bahwa ada pengaruh Prosedur $\left(\mathrm{X}_{2}\right)$ dengan Keberhasilan Implementasi ERP (Y) yaitu sebesar 0,614. . Hasil ini konsisten jika dibandingkan dengan hasil penelitian lainnya sehingga dapat disimpulkan terdapat konsistensi antara konsistensi antara Prosedur dan Keberhasilan Implementasi ERP; (3) hasil penelitian ini menyatakan bahwa ada pengaruh Data $\left(\mathrm{X}_{3}\right)$ dengan Keberhasilan Implementasi ERP $(\mathrm{Y})$ yaitu sebesar 1,084. . Hasil ini konsisten jika dibandingkan dengan hasil penelitian lainnya sehingga dapat disimpulkan terdapat konsistensi antara konsistensi antara Data dan Keberhasilan Implementasi ERP; (4) hasil penelitian ini menyatakan bahwa ada pengaruh Perangkat Keras $\left(\mathrm{X}_{4}\right)$ dengan Keberhasilan Implementasi ERP (Y) yaitu sebesar 1,290. Hasil ini belum dapat dibandingkan dengan hasil penelitian lainnya sehingga belum dapat disimpulkan apakah terdapat konsistensi antara Perangkat Keras dan Keberhasilan Implementasi ERP; (5) hasil penelitian ini menyatakan bahwa ada pengaruh Manajemen Proyek $\left(\mathrm{X}_{5}\right)$ dengan Keberhasilan Implementasi ERP (Y) yaitu sebesar 1,062. Hasil ini belum dapat dibandingkan dengan hasil penelitian lainnya sehingga belum dapat disimpulkan apakah terdapat konsistensi antara Manajemen Proyek dan Keberhasilan Implementasi ERP; (6) hasil penelitian ini menyatakan bahwa ada pengaruh Pengguna Akhir $\left(\mathrm{X}_{1}\right)$, Prosedur $\left(\mathrm{X}_{2}\right)$, Data $\left(\mathrm{X}_{3}\right)$, Perangkat Keras $\left(\mathrm{X}_{4}\right)$ dan Manajemen Proyek $\left(\mathrm{X}_{5}\right)$ secara bersama-sama terhadap Keberhasilan 
Implementasi ERP (Y) sebesar 93,4\% sedangkan 6,6\% dipengaruhi oleh faktor-faktor lain yang ada dalam perusahaan. Hasil ini belum dapat dibandingkan dengan hasil penelitian lainnya sehingga belum dapat disimpulkan apakah terdapat konsistensi antara Pengguna Akhir, Prosedur, Data, Perangkat Keras Manajemen Proyek secara bersama-sama terhadap Keberhasilan Implementasi ERP; (7) hasil penelitian ini menyatakan bahwa Perangkat Keras $\left(\mathrm{X}_{3}\right)$ mempunyai pengaruh yang paling besar terhadaap Keberhasilan Implementasi ERP dibanding variabel bebas lainnya.

Beberapa hal yang perlu mendapat fokus untuk langkah selanjutnya antara lain: (1) untuk peneliti yang berminat mengkaji lebih lanjut pada bidang yang sama maka peneliti tersebut dapat menambah jumlah obyek penelitian perusahaan dengan bidang yang lebih kompleks dan bukan hanya di perusahaan yang bergerak di bidang perdagangan dan manufaktur saja, namun juga perusahan yang bergerak di bidang lain seperti perusahaan ritel, distribusi dan jenis usaha lainnya. Selain itu obyek penelitian dapat dikembangkan dengan mengacu pada wilayah lainnya di luar Jabodetabek; (2) untuk penelitian selanjutnya disarankan untuk dapat memasukan variabel lain yang belum diteliti baik itu variabel bebas (independence variable) baik variabel terikat (dependent variable). Variabel bebas yang dapat diteliti seperti tingkat pengalaman implementor dan tingkat resistensi pengguna sistem ERP dalam perusahaan. Sedangkan untuk variabel terikat yang dapat diteliti misalnya adalah Proses Pengambilan Keputusan; (3) untuk manajemen perusahaan yang telah menjadi obyek penelitian, disarankan untuk menggunakan sistem ERP yang telah diimplementasikan secara maksimal dengan cara mengembangkan sharing knowledge center sehingga kemampuan pengguna akhir dalam mengoperasikan sistem ERP meningkat dan fitur-fitur yang ada dalam sistem ERP dapat dipergunakan sesuai dengan kebutuhan perusahaan. Dalam jangka panjang, sistem ERP dapat ditingkatkan dengan cara membangun data warehouse system yang berkaitan dengan business intelligent yang sangat berguna bagi perusahaan untuk mengembangkan informasi akuntansi dalam berbagai dynamic report dan dashboard yang lebih bermanfaat bagi proses pengambilan keputusan.

\section{DAFTAR PUSTAKA}

Dhewanto, Wawan dan Falahah. (2007). ERP: Menyelaraskan Teknologi Informasi dengan Strategi Bisnis. Jakarta: Informatika.

McLeod Jr., Raymond. (2004). Sistem Informasi Manajemen: Studi Sistem Informasi Berbasis Komputer. Jakarta: Prenhallindo.

Meredith, Jack R and Mantel, Samuel J. (2002). Project Management: A Managerial Approach, (4th ed.). New Jersey: John Wiley \& Sons.

Stair, Ralph M. and Reyolds, George W. (2008). Principles of Information Systems. Stamford: Thomson Course Technology

Turban, Efraim, Mclean, Ephraim and Wetherbe, James. (2001). Information Technoloy for Management: Making Connections for Strategic Advantage. New Jersey: John Wiley \& Sons. 